\title{
PENGARUH PEMBERIAN BUAH MELON TERHADAP PENURUNAN TEKANAN DARAH SISTOLIK DAN DIASTOLIK PADA PENDERITA HIPERTENSI USIA 41-64 TAHUN
}

\section{THE EFFECT OF GIVING MELON FRUIT ON THE REDUCTION OF SISTOLIC BLOOD PRESSURE AND INASTOLIC IN HYPERTENSION PATIENTS AGES 41-64 YEAR}

\author{
Nuke Melati Anindea ${ }^{1}$;Ria Ambarwati ${ }^{2}$;Susi Tursilowati ${ }^{3}$;J. Supadi ${ }^{4}$ \\ ${ }^{1}$ Mahasiswa Jurusan Gizi Politeknik Kesehatan Kemenkes Semarang \\ ${ }^{2,3,4}$ Dosen Jurusan Gizi Politeknik Kesehatan Kemenkes Semarang
}

\begin{abstract}
Background : Hypertension is a health issues that needs attention. Based on Riskesdas Data, prevalence of hypertension increased from 7,6\% in 2007 to 9,5\% in 2013. One of the treatments which can be done is by giving fruits that contain potassium and fiber.

Objective : To determine the effect of melon fruit on the decrease systolic and diastolic blood pressure in patients with hypertension age 41-64 years. Method: This study used Quasi Experiment method with Pretest Posttest Control Group Design. The samples of study was determined by non randomized sampling technique consists of 11 treatments and 11 controls sampels.
\end{abstract}

Results : There was significant difference in systolic and diastolic blood pressure between the treatment and control group $(p<0,05)$. There was no effect of giving melon fruit to decrease systolic $(p=0,071)$ and diastolic $(p=0,042)$ blood pressure in patient hypertension with control variable of sodium, potassium, magnesium, calcium and fiber intake.

Conclusion : Consumption of melon fruit for 9 days can reduce systolic blood pressure $14.82 \pm 5.759 \mathrm{mmHg}$ and diastolic of $7.64 \pm 2.292 \mathrm{mmHg}$, although statistically insignificant.

Keywords : melon, blood pressure, hypertension

\section{ABSTRAK}

Latar Belakang : Hipertensi merupakan masalah kesehatan yang perlu diperhatikan karena prevalensinya yang terus meningkat. Berdasarkan data Riskesdas, terjadi peningkatan hipertensi dari 7,6\% tahun 2007 menjadi $9,5 \%$ pada tahun 2013. Upaya yang dapat dilakukan untuk membantu menurunkan tekanan darah yaitu dengan pemberian buah-buahan yang mengandung kalium dan serat seperti buah melon.

Tujuan : Mengetahui pengaruh pemberian buah melon terhadap tekanan darah sistolik dan diastolik pada penderita hipertensi usia 41 - 64 tahun.

Metode : Penelitian ini termasuk penelitian eksperimen semu dengan desain penelitian pre dan post test control group design.Pengambilan sampel menggunakan teknik non randomized sampling untuk mendapatkan11 sampel perlakuan dan 11sampel kontrol.

Hasil : Ada perbedaan tekanan darah sistolik dan diastolik sebelum dan sesudah pemberian buah melon $(p<0,05)$. Tidak ada hubungan antara pemberian buah melon terhadap tekanan darah sistolik $(p=0,711)$ dan diastolik $(p=0,442)$ pada penderita hipertensi usia 41-64 tahun di Wilayah Kerja Puskesmas Tlogosari Wetan yang dikontrol dengan asupan (kalium, natrium, magnesium, kalsium dan serat).

Kesimpulan : Pemberian buah melon selama 9 hari mampu menurunkan tekanan darah sistolik sebesar $14,82 \pm 5,759 \mathrm{mmHg}$ dan diastolik sebesar 7,64 $\pm 2,292 \mathrm{mmHg}$, walaupun secara statistik tidak signifikan.

Kata kunci : buah melon, tekanandarah, hipertensi 
Hipertensi merupakan masalah kesehatan yang perlu diperhatikan karena merupakan salah satu faktor penting sebagai pemicu penyakit tidak menular, seperti stroke, serangan jantung/infark miokard, edema paru, gagal ginjal, kebutaan, penurunan fungsi kognitif dan pendengaran menurun ${ }^{1}$.

Berdasarkan data Riskesdas 2013, terjadi peningkatan prevalensi hipertensi dari 7,6\% pada tahun 2007 menjadi 9,5\% pada tahun 2013. Jumlah kasus hipertensi di kota Semarang meningkat dari 32.010 pada tahun 2014 menjadi 35.771 pada tahun 2015. Peningkatan jumlah penderita hipertensi tertinggi terdapat di wilayah kerja Puskesmas Tlogosari Wetan yaitu dari 1.967 pada tahun 2014 menjadi 2.173 pada tahun 2015 . $^{2,3}$

Hipertensi berkaitan dengan gaya hidup seseorang yang tidak sehat seperti stress, kurang bergerak (inaktivitas), merokok, konsumsi alcohol, konsumsi garam berlebih dan pola makan salah. Upaya yang dapat dilakukan untuk menurunkan tekanan darah yaitu secara farmakologi dan non farmakologi. Upaya farmakologi adalah dengan penggunan obat-obatan. ${ }^{4}$ Sedangkan, upaya pengobatan non farmakologi dapat dengan olahraga atau aktivitas fisik, manajemen pengendalian stres, dan modifikasi gaya hidup. Modifikasi gaya hidup berupa diet rendah garam, menghindari alkohol dan diet tinggi kalium serta konsumsi buah dan sayuran. Hasil penelitian Wang (2012) mengenai, Fruit and vegetable intake and the risk of hypertension in middle-aged and older women menunjukkan bahwa konsumsi buah dan sayur sebanyak $\geq 5$ porsi/hari dapat mencegah kenaikan tekanan darah.

Buah-buahan yang mengandung kalium dan serat diantaranya adalah pisang, semangka, belimbing dan melon. Kandungan kalium yang cukup tinggi berpengaruh baik bagi sistem saraf, otot, jantung dan pembuluh darah. ${ }^{7}$ Mekanisme kerja kalium adalah dengan cara vasodilatasi yang menyebabkan penurunan retensi perifer total dan meningkatkan output jantung, kalium dapat mengubah aktivitas sistem renin-angiotensin serta mengatur saraf perifer dan sentral yang mempengaruhi tekanan darah. ${ }^{8}$ Selain kalium, serat juga berpengaruhterhadap tekanan darah walaupun tidak berkaitan secara langsung. Konsumsi serat tinggi akan membantu menurunkan kadar kolesterol darah dan kolesterol dalam hati sehingga akan mencegah penumpukan kolesterol di pembuluh darah sehingga tekanan darah tidak mengalami kenaikan. ${ }^{9}$ Kandungan serat dalam buah utuh lebih tinggi bila dibandingkan dengan dibuat jus. ${ }^{10}$
Tujuan dari penelitian ini adalah untuk mengetahui pengaruh pemberian buah melon terhadap tekanan darah sistolik dan diastolik pada penderita hipertensi usia 41-64 tahun. Manfaat penelitian ini yaitu memberikan salah satu alternative sebagai pilihan pangan fungsional dan efektif dalam menurunkan tekanan darah pada penderita yang mengalami hipertensi.

\section{METODE}

Penelitian ini merupakan jenis penelitian eksperimen semu dengan rancangan penelitian adalah experimental pre and post test control group design. Penelitian dilakukan di wilayah kerja puskesmas tlogosari wetan dengan populasi target yaitu pasien yang pertama kali didiagnosa menderita hipertensi usia 41-64 tahun.

Penelitian dilakukan pada bulan April-Mei 2018 dengan besar sampel dihitung menggunakan Uji Hipotesis Beda Rata-rata 2 kelompok independen. Sampel dipilih secara non randomized sampling. Jumlah total sampel 22 orang terdiri dari 11 sampel kelompok perlakuan dan 11 sampel kelompok kontrol. Kelompok perlakuan diberikan buah melon sebnayak 200 gram selama sembilan hari.

Variable independent dalam penelitian ini adalah pemberiah buah melon, variable dependentnya adalah tekanan darah sistolik dan diastolik, sedangkan variable kontrol dari penelitian ini adalah asupan kalium, natrium, magnesium, kalsium dan serat.

Data yang dikumpulkan meliputi data identitas sampel yang diperoleh dengan kuesioner, data tekanan darah sistolik dan diastolik, data konsumsi buah melon, data asupan makanan (kalium, natrium, magnesium, kalsium, serat) dengan metode food recall $3 \times 24$ jam.Tekanan darah sistolik dan diastolik diperoleh dari pengukuran menggunakan sphygmomanometer digital. Pengukuran dilakukan $1 x$ sebelum perlakuan dan $3 x$ selama perlakuan.

Analisis univariat digunakan untuk mendeskripsikan karakteristik sampel dalam bentuk tabel distribusi frekuensi untuk data kategorik dan data berbentuk numerik disajikan dalam bentuk mean dan standar deviasi.Analisis bivariate digunakan untuk menguji perbedaan asupan kalium, natrium, magnesium, kalsium dan serat sebelum dan selama penelitian antara kelompok perlakuan dan kelompok kontrol. Serta utuk menguji perbedaan tekanan darah sistolik dan diastolik sebelum dan sesudah perlakuan. Analisis multivariate menggunakan ANOVA Repeated Measured dengan tingkat kemaknaan $\alpha$ 0,05 . 


\section{HASIL PENELITIAN}

Penelitian ini dilakukan pada penderita hipertensi di wilayah kerja Puskesmas Tlogosari Wetan selama 9 hari dengan total sampel 22 orang, masing-masing kelompok 11 orang.

\section{Karakteristik sampel penelitian}

$$
\text { Karakteristik sampel didapatkan }
$$
melalui wawancara yang diisikan dalam kuesioner penelitian.

Tabel 1. Distribusi frekuensi menurut karakteristik sampel

\begin{tabular}{|c|c|c|c|c|}
\hline \multirow[t]{2}{*}{ Xariabel } & \multicolumn{2}{|c|}{ KelompokRerlakuan } & \multicolumn{2}{|c|}{ KelompakKontrol } \\
\hline & $\mathrm{N}(11)$ & $\%$ & $\mathrm{~N}(11)$ & $\%$ \\
\hline \multicolumn{5}{|c|}{ Karakteristiksampel. } \\
\hline \multicolumn{5}{|l|}{ Ieniskelamin } \\
\hline Laki-laki & 0 & 0 & 1 & 9,1 \\
\hline Bexempuan & 11 & 100 & 10 & 90.9 \\
\hline \multicolumn{5}{|l|}{ Unmur } \\
\hline 41- 49 taburn & 3 & 27,2 & 3 & 27,3 \\
\hline $50-59$ tabuun & 5 & 45,5 & 7 & 63,6 \\
\hline $60-64$ tahum & 3 & 27,3 & 1 & 9,1 \\
\hline \multicolumn{5}{|l|}{ Pendidikan } \\
\hline Tidaksekolah & 2 & 18,2 & 3 & 27,2 \\
\hline Sekelahdasarar & 5 & 45,5 & 3 & 27,3 \\
\hline Seksclahlanjiutan & 4 & 36,4 & 5 & 45,5 \\
\hline
\end{tabular}

2. Keadaan awal sampel penelitian

Keadaan tekanan darah awal sampel penelitian antara kedua kelompok perlu dibandingkan untuk mengetahui homogenitas sampel sebelum diberi perlakuan.

3. Asupan natrium, kalium, magnesium, kalsium dan serat sebelum dan selama penelitian antara kelompok perlakuan dan kelompok kontrol

Asupan makan yang dilihat pada penelitian ini adalah asupan kalium, natrium, magnesium, kalsium dan serat yang merupakan faktor yang dapat berpengaruh terhadap tekanan darah sistolik dan diastolik. Rata-rata asupan kalium, natrium, magnesium, kalsium dan serat antara kelompok perlakuan dan kelompok kontrol sebelum dan selama penelitian dapat dilihat pada tabel 3 .

Tabel 2. Tekanan darah sistolik dan diastolik sampel penelitian sebelum perlakuan antara kelompok perlakuan dan kelompok kontrol

\begin{tabular}{|c|c|c|c|c|c|c|c|}
\hline \multirow[t]{2}{*}{ Variabel } & \multicolumn{3}{|c|}{ Kelompok perlakuan (n=11) } & \multicolumn{3}{|c|}{ Kelompok kontrol (n=11) } & \multirow{2}{*}{$\mathbf{P}$} \\
\hline & Mean \pm SD & Min & $\operatorname{Max}$ & Mean \pm SD & Min & $\operatorname{Max}$ & \\
\hline TDS & $163,00 \pm 10,29$ & 146 & 177 & $158,09 \pm 12,2$ & 144 & 180 & $0,321^{2}$ \\
\hline TDD & $99,64 \pm 3,17$ & 95 & 105 & $97,45 \pm 3,59$ & 93 & 103 & $0,146^{2}$ \\
\hline
\end{tabular}

Tabel 3. Perbedaan asupan natrium, kalium, magnesium, kalsium dan serat antara kelompok perlakuan dan kelompok kontrol sebelum dan selama penelitian

\begin{tabular}{|c|c|c|c|}
\hline Asupan & Kelompok perlakuan & Kelompok kontrol & $\mathbf{P}$ \\
\hline & Mean $+5 \mathrm{D}$ & Mean $+5 \mathrm{D}$ & \\
\hline \multicolumn{4}{|l|}{$\begin{array}{l}\text { Sebelum } \\
\text { penelitian }\end{array}$} \\
\hline Natrium & $1268,4 \pm 328,44$ & $1246,3 \pm 251,05$ & $0,818^{t}$ \\
\hline Kalium & $852,35 \pm 146,48$ & $815,92 \pm 122,6$ & $0,534^{2}$ \\
\hline Magnesium & $178,06 \pm 29,85$ & $174,45 \pm 39,12$ & $0,810^{\circ}$ \\
\hline Kalsium & $170,15 \pm 56,03$ & $168,2 \pm 46,24$ & $0,930^{\circ}$ \\
\hline Serat & $7,309 \pm 1,62$ & $7,300 \pm 1,42$ & $0,989=$ \\
\hline \multicolumn{4}{|l|}{$\begin{array}{l}\text { Selama } \\
\text { penelitian }\end{array}$} \\
\hline Natrium & $1110,2 \pm 120,37$ & $1063,468 \pm 133,7$ & $0,399:$ \\
\hline Kalium & $1409,91 \pm 247,09$ & $841,88 \pm 155,9$ & $0,000^{\mathrm{t}}$ \\
\hline Magnesium & $181,96 \pm 31,47$ & $178,18 \pm 39,8$ & $0,792^{\circ}$ \\
\hline Kalsium & $186,71 \pm 65,63$ & $180,0 \pm 39,0$ & $0,718^{t}$ \\
\hline Serat & $7,69 \pm 1,2$ & $7,65 \pm 1,82$ & $0.956^{\circ}$ \\
\hline
\end{tabular}

Hasil analisis ada perbedaan yang bermakna asupan kalium selama perlakuan $(p<0,05)$. Namun, asupan natrium, magnesium, kalsium dan serat antara kelompok perlakuan dan kelompok kontrol baik sebelum dan sesudah penelitian tidak ada perbedaan.

4. Perbedaan Selisih Tekanan darah sistolik dan diastolik sebelum dan sesudah pemberian buah melon antara kelompok perlakuan dengan kelompok kontrol

Perbedaan tekanan darah sistolik dan diastolik sebelum dan sesudah pemberian melon antara kelompok perlakukan dan kontrol dapat dilihat pada tabel 4 .

Tabel 4. Tekanan darah sistolik dan diastolik sebelum dan sesudah perlakuan antara kelompok perlakuan dankelompok kontrol

\begin{tabular}{|c|c|c|c|c|}
\hline \multirow{2}{*}{$\begin{array}{l}\text { Tekanan } \\
\text { darah }\end{array}$} & \multicolumn{2}{|c|}{ Kelompok perlakuan } & \multicolumn{2}{|c|}{ Kelompok control } \\
\hline & Mean \pm SD & $\mathrm{P}$ & Mean \pm DD & $\mathrm{P}$ \\
\hline \multicolumn{5}{|l|}{ TDS } \\
\hline Awal & $163,00 \pm 10,286$ & $0,000^{2}$ & $158,09 \pm 12,267$ & $0,082^{a}$ \\
\hline Akhir & $148,18 \pm 6,385$ & & $156,73 \pm 11,620$ & \\
\hline$\Delta$ & $14,82 \pm 5,76$ & & $1,36 \pm 2,33$ & \\
\hline \multicolumn{5}{|l|}{ TDD } \\
\hline Awal & $99,64 \pm 3,171$ & $0,003^{b}$ & $97.45 \pm 3,588$ & $0,034^{2}$ \\
\hline Akhir & $92,00 \pm 2,757$ & & $96,27 \pm 3,552$ & \\
\hline$\Delta$ & $7,64 \pm 2,29$ & & $1,18 \pm 1,60$ & \\
\hline
\end{tabular}

5. Pengaruh pemberiah buah melon terhadap tekanan darah sistolik dan diastolik pada kelompok perlakuan dan kelompok kontrol

Uji ANOVA Repeated Measured didapatkan $(p=0,711)$ untuk tekanan darah sistolik dan $(p=0,442)$ untuk tekanan darah diastolik. Tren penurunan tekanan darah selama penelitian dapat dilihat pada gambar 1 dan 2. 


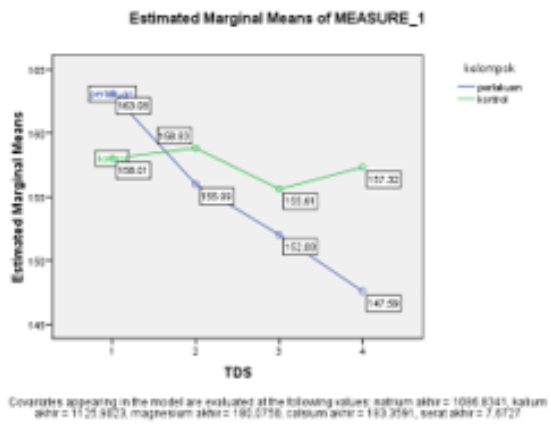

\section{Gambar 1. Grafik Tekanan Darah Sistolik antara Kelompok}

Perlakuan dan Kelompok Kontrol Setiap pengukuran Selama Penelitian dengan Variabel Kontrol (Asupan Kalium, Natrium, Magnesium, Kalsium dan Serat)

Pengukuran tekanan darah dilakukan sebanyak 4 kali. Pengukuran pertama yaitu pada sebelum penelitian dan pengukuran selanjutnya pada hari ke 3, 6 dan 9. Tekanan darah sistolik pada kelompok perlakuan cenderung turun terus menerus selama penelitian. Pada kelompok perlakuan, pada pengukuran kedua sudah terlihat mengalami penurunan yang semula $163,08 \mathrm{mmHg}$ menjadi $155,99 \mathrm{mmHg}$. Pada hari pengukuran ketiga, tekanan darah turun menjadi $152,03 \mathrm{mmHg}$ dan pengukuran keempat turun menjadi $147,59 \mathrm{mmHg}$. Sedangkan, pada kelompok kontrol, tekanan darah sistolik cenderung naik turun. Pada pengukuran kedua pada grafik terlihat naik, yang semula 158,01 $\mathrm{mmHg}$ menjadi 158,83 . Namun, pada pengukuran ketiga turun kembali menjadi $155,61 \mathrm{mmHg}$ dan kembalinaik pada pengukuran keempat menjadi $157,32 \mathrm{mmHg}$.

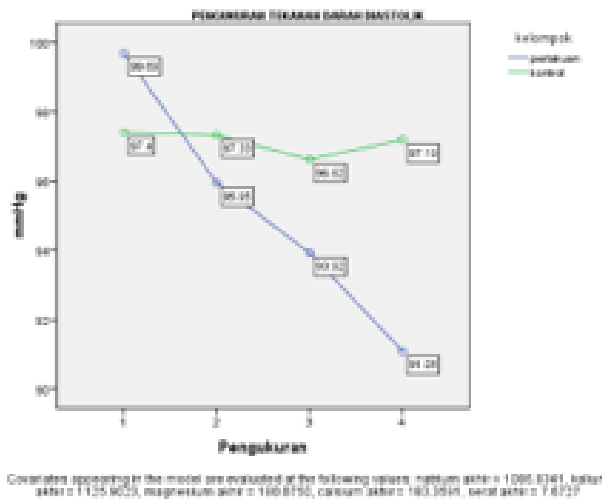

Gambar 2. Grafik Tekanan Darah Diastolik antara Kelompok Perlakuan dan Kelompok Kontrol Setiap pengukuran Selama Penelitian dengan Variabel Kontrol (Asupan Kalium, Natrium, Magnesium, Kalsium dan Serat)

Penurunan tekanan darah diastolik pada kelompok perlakuan mulai terlihat pada hari ketiga atau pengukuran kedua yaitu yang semula 99,69 mmHg menjadi 95,95 $\mathrm{mmHg}$ dan cenderung turun hingga akhir penelitian. Tekanan darah diastolik mencapai angka 93,92 $\mathrm{mmHg}$ dan 91,08 $\mathrm{mmHg}$ pada pengukuran ketiga dan keempat. Penurunan terbesar terdapat pada pengukuran kedua sebesar 3,74 $\mathrm{mmHg}$. Tekanan darah diastolik pada kelompok kontrol cenderung turun pada pengukuran kedua dan ketiga yaitu semula $97,4 \mathrm{mmHg}$ menjadi 97,33 dan 96,62 $\mathrm{mmHg}$, tetapi pada pengukuran keempat naik kembali menjadi 97,19 $\mathrm{mmHg}$.

Penurunan tekanan darah pada kelompok perlakuan lebih besar dibandingkan kelompok kontrol, hal ini dikarenakan pada kelompok perlakuan diberi buah melon sebanyak 200 gram dengan kalium sebanyak $534 \mathrm{mg}$ selama 9 hari. Adanya peningkatan asupan kalium dapat berpengaruh terhadap tekanan darah. Menurut Weaver, peningkatan kadar kalium plasma yang bersumber dari diet kaya kalium berkaitan dengan efek vasodilatasi endotel sehingga tekanan darah menurun. ${ }^{23}$ Untuk menurunkan tekanan darah dan mencegah risiko penyakit kardiovaskuler tubuh memerlukan asupan kalium sekitar $\pm 4,7$ gram per hari atau sesuai rekomendasi DASH diet yaitu konsumsi buah dan sayur masingmasing 4-5 porsi setiap hari. Sedangkan dalam penelitian ini hanya menyumbangkan sekitar $11,3 \%$ kalium. Cara kerja kalium berbanding terbalik dengan cara kerja natrium. Kalium bekerja dengan cara vasodilatasi dan mengubah system renin-angiotensin yang dapat mempengaruhi tekanan darah. ${ }^{11,12,13}$

Pengaruh pemberian kalium dalam buah melon terhadap tekanan darahsetelah dikontrol dengan asupan natrium, kalium, magnesium, kalsium dan serat didapatkan nilai $(p>0,05)$. Dengan kata lain, ada pengaruh yang tidak signifikan antara pemberian buah melon terhadap tekanan darah. Ketidaksignifikanan dapat terjadi dikarenakan oleh waktu intervensi yang kurang lama atau frekuensi pemberian buah yang kurang banyak.

Penurunan tekanan darah berkaitan dengan mekanisme kerja kalium. Kalium berperan dalam mekanisme penurunan tekanan darah dan cara kerjanya berlawanan 
dengan natrium,. Kalium bersifat natriuresis yaitu menghambat reabsopsi natrium di tubulus proximal dan menekan sekresi renin angiotensin. Selain itu, kalium juga dapat menyebabkan relaksasi otot polos dengan meningkatkan produksi NO (nitric oxide). ${ }^{14,15}$ Kalium dapat mempengaruhi system renin angiotensin, dimana kalium menghambat pengeluaran renin yang seharusnya mengubah angiotensin menjadi angiotensin I, karena adanya blok system ini maka pembuluh darah akan mengalami vasodilatasi yang mengakibatkan relaksasi pada dinding pembuluh darah yang pada akhirnya akan menurunkan tekanan darah.Komponen lain yang terdapat dalam buah melon selain kalium adalah kalsium. Walaupun tidak terlalu dominan tetapi kalsium berfungsi sebagai pengatur ritme jantung agar lebih teratur. Kalsium juga dapat menjaga keseimbangan natrium dan kalium dalam darah. ${ }^{16,17}$ Penelitian Wang dalam Dietary Intake of Dairy Products, Calcium, and Vitamin $D$ and the Risk of Hypertension in Middle-Aged and Older Women menjelaskan bahwa kebiasaan mengonsumsi produk tinggi kalsium mampu menurunkan risiko hipertensi karena kalsium dapat menurunkan aktifitas reninangiotensin,memperbaiki keseimbangan natrium-kalium, mencegah kontraksi oto polos. Oleh karena itu, kalium yang tingi serta kalsium dalam melon merupakan komponen penting dalam menurunkan tekanan darah. ${ }^{18,19,20}$

Selain kalium dan kalsium, komponen lain yang diduga mampu menurunkan tekanan darah yaitu serat. Serat berperan secara tidak langsung dalam penurunan tekanan darah. Konsumsi serat tinggi akan membantu menurunkan kadar kolesterol darah dan kolesterol dalam hati sehingga akan mencegah penumpukan kolesterol di pembuluh darah. Penumpukan kolesterol di pembuluh darah akan membentuk plak. Terbentuknya plak dapat menyebabkan penyumbatan pembuluh darah atau aterosklerosis yang selanjutnya dapat menyebabkan peningkatan tekanan darah. Maka dari itu, konsumsi serat dalam jumlah yang cukup dapat menurunkan resiko tekanan darah tinggi. ${ }^{21}$ Penelitian Streppel menunjukkan bahwa suplemen serat 11,5 $\mathrm{gr} /$ hari dapat menurunkan tekanan darah sistolik 1,13 mmHg dan 1,26 tekanan diastolik pada penderita hipertensi yang berusia $>40$ tahun. ${ }^{22}$

Adanya penurunan tekanan darah sistolik dan diastolik pada sampel penelitian ini sejalan dengan penelitian Elis (2017) pemberian buah melon sebanyak 200 gram selama 5 hari mampu menurunkan tekanan darah sistolik sebesar 14,67 $\mathrm{mmHg}$ dan tekanan darah sistolik sebesar $10,33 \mathrm{mmHg}^{16}$ Penelitian Bimanteri (2014) mengenai pengaruh pemberian jus buah melon terhadap tekanan darah penderita hipertensi di modinan banyuraden, sleman yang hasilnya jus buah melon dapat menurunkan tekanan darah sehingga dapat dijadikan terapi antihipertensi nonfarmakologi. ${ }^{18}$ penurunan tekanan darah juga berkaitan dengan factor-faktor lain.

\section{KESIMPULAN}

Kesimpulan pada penelitian ini yaitu ada perbedaan yang bermakna tekanan darah sistolik dan diastolik $(p<0,05)$ sebelum dan sesudah perlakuan pada kelompok perlakuan. Sedangkan, pada kelompok kontrol tidak ada perbedaan tekanan darah sistolik $(p>0,05)$ sedangkan tekanan darah diastolik ada perbedaan $(p<0,05)$. Pemberian buah melon selama 9 hari mampu menurunkan tekanan darah sistolik sebesar $14,82 \pm 5,759 \mathrm{mmHg}$ dan diastolik sebesar $7,64 \pm 2,292 \mathrm{mmHg}$, walaupun secara statistik tidak signifikan.

\section{SARAN}

Penderita hipertensi diharapkan agar mengonsumsi bahan makanan tinggi kalium dan serat seperti buah melon serta rutin memeriksakan tekanan darahnya. Untuk penelitian selanjutnya disarankan untuk memantau tekanan darah pretest dan post test setiap hari agar dapat diketahui pada hari keberapa mulai terjadi penurunan tekanan darah.

\section{DAFTAR PUSTAKA}

1. Farquhar W., D.G E, W.S W. Dietary sodium and health: More than just blood pressure. J Am. 2015;65:1042-50.

2. Dinas Kesehatan Kota Semarang. Profil Kesehatan Kota Semarang 2014. Semarang: Dinas Kesehatan Kota Semarang, 2015.

3. Dinas Kesehatan Provinsi Jawa Tengah. Buku Saku Kesehatan Triwulan 3 Tahun 2015. Semarang: Dinas Kesehatan Provinsi Jawa Tengah, 2015.

4. Palmer, A dan William, B. Tekanan Darah Tinggi. Jakarta : Erlangga,2007.

5. Marliani,L. 100 Question \& Answers Hipertensi. Jakarta : PT Elex Media Komputindo, Gramedia, 2007.

6. Wang,Lu , JoAnn E. Manson. "Fruit and vegetable intake and the risk of hypertension 
in middle-aged and older women". Am J Hypertens; 2012; 25(2) :180-189.

7. Kowalski R. program 8 Minggu menurunkan tekanan Darah Tinggi dan Mengurangi Risiko Serangan Jantung dan Stroke Secara Alami. Bandung: PT Mizan Pustaka; 2010.

8. Astawan, M. Khasiat Warna Warni Makanan. Jakarta : PT Gramedia Pustaka Utama; 2008.

9. Santawati F. hubungan asupan serat dengan beberapa faktor risiko penyakit kardiovaskuler. Artik Penelit. 2010;

10. Griep O, J S, Q C. Association of raw fruit and fruit juice consumption with blood pressure: the INTERMAP Study. Am J Clin. 2013;97(5):1083-91.

11. Almatsier S. Prinsip Dasar Ilmu Gizi. Jakarta: Gramedia Pustaka Utama; 2009.

12. Press BUNJ. Kadar $\mathrm{Na}+, \mathrm{K}+, \mathrm{Cl}-$, dan Kalium Total Serum Darah Serta Hubungannya dengan Tekanan Darah pada Penderita Hipertensi Puspita Anggraini, Rusdi \& Ermita Ibrahim Ilyas. 2016;12(1):50-66.

13. Campbell AP. DASH Eating Plan: An Eating Pattern for Diabetes Management. spectrum.diabetes journals [Internet]. 2017;30. Available from: https://doi.org/10.2337/ds16-0084

14. Nguyen H, Odeola O, Rangaswami J, Amanullah A. A Review of Nutritional Factors in hypertension Management. Int J Hypertens. 2013;

15. Oberleithner $\mathrm{H}$, Callies $\mathrm{C}$, et al. Potassium softens Vascular endothelium and increases nitric oxide release. PNAS. 2009;106(8):282934.

16. Elis, Marsuni. Pengaruh Pemberian Jus Pepaya, Jus Semangka, Jus Melon terhadap penderita tekanan darah sistolik dan diastolik," Skripsi S1 Gizi Semarang UNDIP, 2007.

17. Dedeh. Budidaya Melon. Bandung : Nobel Edumedia, , 2009.

18. Publikasi N, Bimanteri L, Studi P, Keperawatan I. Pengaruh Pemberian Jus Melon Terhadap Tekanan Darah Penderita Hipertensi di Modinan Banyuraden Seman Yogyakarta. 2014;

19. Wang $Q, A A D, T P, m$ burnier. potassium suplementation reduces cardiac and renal hypertrophy independent of blood pressure in DOCA/salt mice. Hypertension. 2005;46:547-54

20. Jorde $\mathrm{R}$, Bonaa $\mathrm{KH}$. Calcium from dairy products, vitamin $\mathrm{D}$ intake, and blood pressure : to Tromo Study, AM J Clin Nutr, 2000, 71:1530,5.
21. $Y Y, L G ~ Z, Q J W$. Association Between Dietary Fiber and Lower Risk of All- Cause mortality : a meta-analysis of Cohort studies. Am J Epidemiol. 2015;181(2):83-91.

22. Streppel M, Arends I r. blood pressure response to calcium supplementation:a meta-analysis of randomized controlled trials. J Hum Hypertens. 2006;20(8):571-80. Weaver C. Potassium and Health. Adavnces Nutr. 2013;4(3):368s-377s 